\title{
Arsenicin A, A Natural Polyarsenical: Synthesis and Crystal Structure
}

\author{
Di Lu, A. David Rae, Geoff Salem, Michelle L. Weir, Anthony C. Willis, and S. Bruce Wild* \\ Research School of Chemistry, Australian National University, Canberra, Australian Capital Territory 0200 , \\ Australia
}

Received November 16, 2009

Summary: The synthesis of the natural polyarsenical Arsenicin $A$ and its crystal structure are described. The molecule has the adamantane-type structure of arsenic trioxide in which three of the oxygen atoms have been replaced by methylene groups to generate four arsenic stereocenters of the same configuration in each enantiomer of the racemate.

The first natural polyarsenical, Arsenicin A, has recently been isolated in trace amounts from the New Caledonian sponge Echinochalina bargibanti and shown to have potent bactericidal and fungicidal activities on human pathogenic strains. ${ }^{1}$ A novel adamantane-type structure related to that of arsenic trioxide in the solid state was proposed for Arsenicin A on the basis of the synthesis of a model compound and detailed spectroscopic measurements and theoretical calculations. ${ }^{1,2}$ In view of the discovery that arsenic trioxide $\left(\mathrm{As}_{2} \mathrm{O}_{3}\right.$, Trisenox) brings about complete remission in a large proportion of patients suffering from acute promyelocytic leukemia (APL), a subtype of acute myeloid leukemia $(\mathrm{AML}){ }^{3}$ we have synthesized Arsenicin A to confirm its structure and to carry out detailed investigations of its biological activity.

The putative structure of Arsenicin $\mathrm{A},\left(R_{\mathrm{As}}{ }^{*}, R_{\mathrm{As}}{ }^{*}, R_{\mathrm{As}}{ }^{*}\right.$, $\left.R_{\mathrm{As}}{ }^{*}\right)-( \pm)-1$, resembles the adamantane-type structure of $\mathrm{As}_{4} \mathrm{O}_{6}$ in which three of the oxygen atoms have been replaced by methylene groups. ${ }^{1}$ Indeed, the $C_{2}$ arrangement of the four arsenic stereocenters in the proposed structure suggested a two-step synthesis of Arsenicin A from the tetrakis(tertiary arsine) $\left(R_{\mathrm{As}}{ }^{*}, R_{\mathrm{As}}{ }^{*}\right)-( \pm)-/\left(R_{\mathrm{As}}{ }^{*}, S_{\mathrm{As}}{ }^{*}\right)-2$, which was synthesized from methylenebis(phenylarsinic acid) ${ }^{4}$ as shown in Scheme 1. ${ }^{5}$

*To whom correspondence should be addressed. Fax: $+(0) 26125$ 0750. Tel: +(0)2 6125 4236. E-mail: sbw@rsc.anu.edu.au.

(1) Mancini, I.; Guella, G.; Frostin, M.; Hnawia, E.; Laurent, D.; Debitus, C.; Pietra, F. Chem. Eur. J. 2006, 12, 8989.

(2) Tahtinen, P.; Saielli, G.; Guella, G.; Mancini, I.; Bagno, A. Chem. Eur. J. 2008, 14, 10445.

(3) (a) Evens, A. M.; Tallman, M. S.; Gartenhaus, R. B. Leuk. Res. 2004, 28, 891. (b) Miller, W. H.Jr.; Schipper, H. M.; Lee, J. S.; Singer, J.; Waxman, S. Cancer Res. 2002, 62, 3893. (c) Chen, H.; MacDonald, R. C.; Li, S.; Krett, N. L.; Rosen, S. T.; O'Halloran, T. V. J. Am. Chem. Soc. 2006, 128, 13348 .

(4) Sommer, K. Z. Anorg. Allg. Chem. 1970, 377, 120.

(5) Synthesis of $\left(R_{\mathrm{As}}{ }^{*}, R_{\mathrm{As}}{ }^{*}\right)-( \pm)-/\left(R_{\mathrm{As}}{ }^{*}, S_{\mathrm{As}}{ }^{*}\right)-2$ : the reduction of methylenebis(phenylarsinic acid) ${ }^{4}$ with an 8 -fold excess of sodium borohydride in methanol at $-78{ }^{\circ} \mathrm{C}$ gave $\left(R_{\mathrm{As}}{ }^{*}, R_{\mathrm{As}}{ }^{*}\right)-( \pm)-/\left(R_{\mathrm{As}}{ }^{*}\right.$, $S_{\mathrm{As}}{ }^{*}$ )-methylenebis(phenylarsine) in $53 \%$ yield after distillation. Deprotonation of the bis(secondary arsine) with 2 equiv of $n$-butyllithium in the presence of tetramethyl-1,2-ethylenediamine (TMEDA) gave [ $\mathrm{Li}(\mathrm{TMEDA})]_{2}\left[\mathrm{CH}_{2}(\mathrm{AsPh})_{2}\right]$, which was isolated as a yellow crystalline solid and treated with 2 equiv of (chloromethyl)diphenylarsine ${ }^{6}$ in THF.

The pure tetraarsine was isolated as a colorless liquid following elution with dichloromethane $-n$-hexane from a silica plate with use of a Chromatotron.

(6) Sommer, K. Z. Anorg. Allg. Chem. 1970, 377, 128.

Scheme 1. Synthesis of the Tetrakis(tertiary arsine)

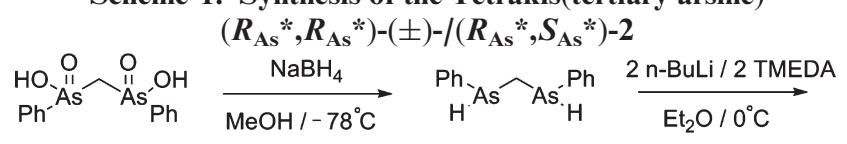

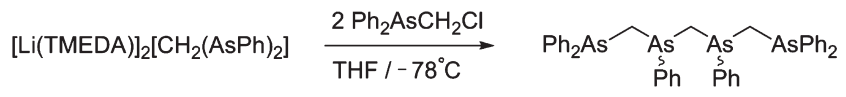

$\left(R^{*}, R^{\star}\right)-( \pm) /\left(R^{*}, S^{\star}\right)-2$

Scheme 2. Synthetic Sequence Leading to Synthesis of Arsenicin $\mathrm{A},\left(\boldsymbol{R}_{\mathrm{As}}{ }^{*}, \boldsymbol{R}_{\mathrm{As}}{ }^{*}, \boldsymbol{R}_{\mathrm{As}}{ }^{*}, \boldsymbol{R}_{\mathrm{As}}{ }^{*}\right)-( \pm)-1$

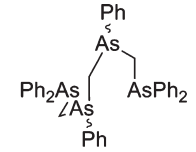

$\left(R^{*}, R^{*}\right)-( \pm) /\left(R^{*}, S^{*}\right)-2$

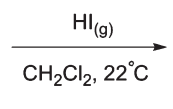

\section{(1)}

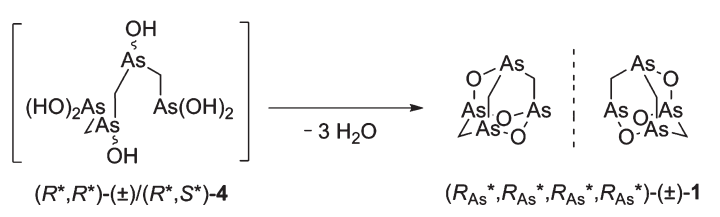

The reaction of $\left(R_{\mathrm{As}}{ }^{*}, R_{\mathrm{As}}{ }^{*}\right)-( \pm)-/\left(R_{\mathrm{As}}{ }^{*}, S_{\mathrm{As}}{ }^{*}\right)-2$ with an excess of anhydrous hydrogen iodide in dichloromethane generated the hexaiodoarsine $\left(R_{\mathrm{As}}{ }^{*}, R_{\mathrm{As}}{ }^{*}\right)-( \pm)-/\left(R_{\mathrm{As}}{ }^{*}, S_{\mathrm{As}}{ }^{*}\right)-$ 3, which, upon hydrolysis with aqueous ammonia, afforded $\left(R_{\mathrm{As}}{ }^{*}, R_{\mathrm{As}}{ }^{*}, R_{\mathrm{As}}{ }^{*}, R_{\mathrm{As}}{ }^{*}\right)-( \pm)-1$ by dehydration of the intermediate hexahydroxoarsine $\left(R_{\mathrm{As}}{ }^{*}, R_{\mathrm{As}}{ }^{*}\right)-( \pm) /\left(R_{\mathrm{As}}{ }^{*}, S_{\mathrm{As}}{ }^{*}\right)-4$, as indicated in Scheme 2. The product was isolated in $43 \%$ yield as air-stable, colorless prisms having mp $182-184{ }^{\circ} \mathrm{C}$ following column chromatography of the crude product on silica and recrystallization from benzene and was characterized by NMR spectroscopy, high-resolution mass spectrometry, elemental analysis, and an X-ray crystal structure determination.

The ${ }^{1} \mathrm{H}$ NMR spectrum of $\left(R_{\mathrm{As}}{ }^{*}, R_{\mathrm{As}}{ }^{*}, R_{\mathrm{As}}{ }^{*}, R_{\mathrm{As}}{ }^{*}\right)-( \pm)-1$ in chloroform- $d$ is consistent with the presence of three methylene groups, two of which are magnetically equivalent due to the $C_{2}$ symmetry of the molecule. Thus, two sets of doublets were observed in the ${ }^{1} \mathrm{H}$ NMR spectrum for the external methylene protons, one at $\delta 2.42$ for $\mathrm{H}(12)$ and $\mathrm{H}(22)$ and the other at $\delta 1.38$ for $\mathrm{H}(11)$ and $\mathrm{H}(21)$, both of which have identical coupling constants $\left({ }^{2} J_{\mathrm{HH}}=13.8 \mathrm{~Hz}\right)$, and a singlet for the internal methylene protons at $\delta 2.23$ for $H(31)$ and $H(32)$, as shown in Figure 1. (The peak in the spectrum at $\delta 1.58$ is due to a trace of water in the solvent.) 


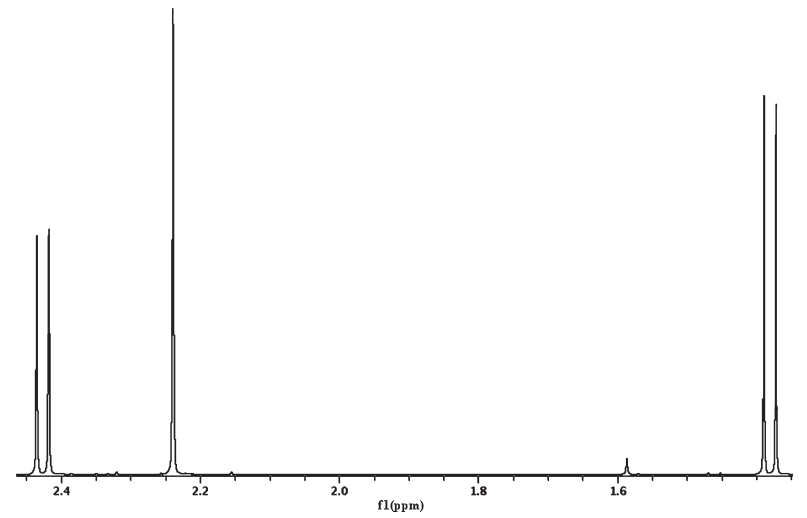

Figure 1. ${ }^{1} \mathrm{H}$ NMR spectrum (800 MHz, chloroform- $d$ ) of Arsenicin A.

The ${ }^{13} \mathrm{C}\left\{{ }^{1} \mathrm{H}\right\}$ NMR spectrum for the compound in the same solvent (chloroform- $d$ ) contained singlets at $\delta 17.2$ for $\mathrm{C}(3)$ and $\delta 23.1$ for $\mathrm{C}(1)$ and $\mathrm{C}(2)$. These NMR spectroscopic data agree with those reported for the polyarsenical isolated from the New Caledonian marine sponge Echinochalina bargibanti. ${ }^{1}$ The HR-EI mass spectrum of Arsenicin A contains a peak for the molecular ion at $\mathrm{m} / \mathrm{z} 389.7183$ $\left(\mathrm{C}_{3} \mathrm{H}_{6} \mathrm{As}_{4} \mathrm{O}_{3}\right.$ requires $m / z$ 389.7181).

Arsenicin A crystallizes from benzene as a racemic compound in the centrosymmetrical space group $P \overline{1}^{7}$ The unit cell of the structure contains two independent pairs of molecules, the molecules in each pair being related by an inversion center. The structure of one of the independent molecules of $\left(S_{\mathrm{As}}, S_{\mathrm{As}}, S_{\mathrm{As}}, S_{\mathrm{As}}\right)-\mathbf{1}$ is shown in Figure 2. The molecule has approximate $C_{2}$ symmetry, the 2-fold rotation axis passing through $\mathrm{O}(2)$ and $\mathrm{C}(3)$. The mean bond lengths $(\AA)$ and angles (deg) in the structure are as follows: As $-\mathrm{C}=1.949(18), \mathrm{As}-\mathrm{O}=1.791(17), \mathrm{As}-\mathrm{C}-\mathrm{As}=$ $120.9(7), \mathrm{As}-\mathrm{O}-\mathrm{As}=130.0(12), \mathrm{C}-\mathrm{As}-\mathrm{C}=99.4(11)$,

(7) Crystal data for $\left(R_{\mathrm{As}}{ }^{*}, R_{\mathrm{As}}{ }^{*}, R_{\mathrm{As}}{ }^{*}, R_{\mathrm{As}}{ }^{*}\right)-( \pm)-1: \mathrm{C}_{3} \mathrm{H}_{6} \mathrm{As}_{4} \mathrm{O}_{3}$; triclinic; space group $P \overline{1}$; unit cell dimensions $a=7.3954(6) \AA, b=$ 11.4072(10) $\AA, c=11.5554(9) \AA, \alpha=118.772(3)^{\circ}, \beta=90.380(3)^{\circ}, \gamma=$ $90.766(3)^{\circ} ; V=854.30(12) \AA^{3} ; Z=4$; calculated density $3.030 \mathrm{Mg} \mathrm{m}^{-3}$; $T=295 \mathrm{~K} ; \lambda=0.71073 \AA ; 14095$ reflections collected; 3884 independent reflections $\left(R_{\mathrm{int}}=0.092\right) ; \theta_{\max }=27.5^{\circ}$; absorption corrected by integration via Gaussian method implemented in maXus (2000); refinement method full-matrix least squares on $F^{2}$; no. of data/parameters 3884/182; $\mathrm{GOF}=0.99$; final R1 $\left(F^{2}>2 \sigma\left(F^{2}\right)\right)=0.062$, wR $2\left(F^{2}\right)=0.182$. All of the crystals of this compound examined were twinned. The nature of the twinning was identified and the ratio of the two components refined.

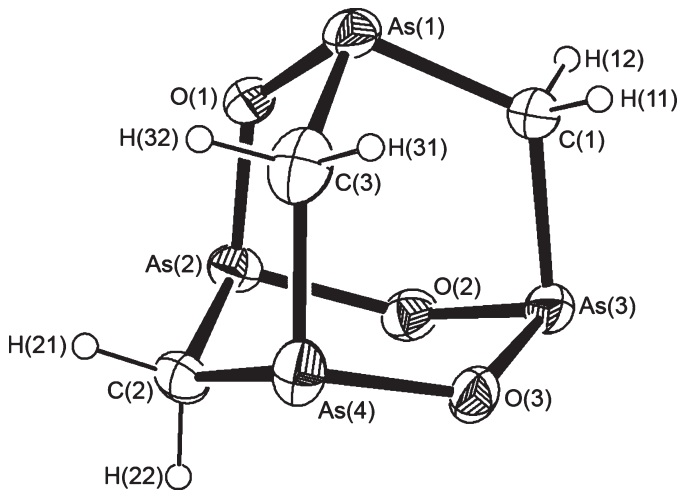

Figure 2. Structure of the $S$ enantiomer of synthetic Arsenicin A. The ellipsoids are shown at the $30 \%$ probability level.

$\mathrm{O}-\mathrm{As}-\mathrm{O}=101.6(9), \mathrm{C}-\mathrm{As}-\mathrm{O}=100.4(8)$. For the related compound 1,3,5,7-tetraarsa-2,4,6,8-tetraoxaadamantane, $\mathrm{As}_{4} \mathrm{O}_{4}\left(\mathrm{CH}_{2}\right)_{2}$, which crystallizes in the space group $P 2_{1} / c$, the mean interatomic distances $(\AA)$ and angles (deg) are as follows: $\mathrm{As}-\mathrm{C}=1.962(16), \mathrm{As}-\mathrm{O}=1.795(18), \mathrm{As}-\mathrm{C}-\mathrm{As}=$ 119.4(6), $\mathrm{As}-\mathrm{O}-\mathrm{As}=129.0(12), \mathrm{O}-\mathrm{As}-\mathrm{O}=101.8(7)$, $\mathrm{C}-\mathrm{As}-\mathrm{O}=99.3(10){ }^{8}$

The novel adamantane-type structure of Arsenicin A poses challenging questions about its biosynthesis and relationship to the variety of known marine organoarsenicals. ${ }^{9}$ It is hoped that the synthesis presented here will facilitate further chemical and biological work on this unusual natural product.

Acknowledgment. We thank Professor George Koutsantonis of the University of Western Australia for alerting us to the existence of this interesting compound.

Supporting Information Available: Text, figures, and a CIF file giving full experimental procedures, spectroscopic data, copies of ${ }^{1} \mathrm{H}$ and ${ }^{13} \mathrm{C}$ NMR spectra, and crystallographic data for $\left(R_{\mathrm{As}}{ }^{*}, R_{\mathrm{As}}{ }^{*}, R_{\mathrm{As}}{ }^{*}, R_{\mathrm{As}}{ }^{*}\right)-( \pm)-\mathbf{1}$. This material is available free of charge via the Internet at http://pubs.acs.org. Crystal data are also available from the Cambridge Crystallographic Database as file number CCDC 752018.

(8) Kopf, J.; von Deuten, K.; Klar, G. Inorg. Chim. Acta 1980, 38, 67.

(9) Francesconi, K. A.; Keuhnelt, D. In Environmental Chemistry of Arsenic; Frankenberger, W. T., Jr., Ed.; Marcel Dekker: New York, 2002; Chapter 3, pp 51-116. 